Correction

\title{
Correction: Mauro, A., et al. Biological Control Products for Aflatoxin Prevention in Italy: Commercial Field Evaluation of Atoxigenic Aspergillus flavus Active Ingredients. Toxins 2018, 10, 30
}

\author{
Antonio Mauro ${ }^{1} ®$, Esther Garcia-Cela ${ }^{2} ®$, Amedeo Pietri ${ }^{3}$, Peter J. Cotty ${ }^{4}$ \\ and Paola Battilani $5, * \mathbb{C}$ \\ 1 International Institute of Tropical Agriculture, Dar es Salaam P.O. Box 34441, Tanzania; a.mauro@cgiar.org \\ 2 Applied Mycology Group, Environment and AgriFood Theme, Cranfield University, Cranfield, \\ Bedford MK43 0AL, UK; m.e.garcia-cela@cranfield.ac.uk \\ 3 Institute of Food Science and Nutrition, Università Cattolica del Sacro Cuore, 29100 Piacenza, Italy; \\ amedeo.pietri@unicatt.it \\ 4 United States Department of Agriculture, Agricultural Research Service, School of Plant Sciences, University \\ of Arizona, Tucson, AZ 85721, USA; Peter.Cotty@ARS.USDA.GOV \\ 5 Department Sustainable Crop Production, Università Cattolica del Sacro Cuore, 29100 Piacenza, Italy \\ * Correspondence: paola.battilani@unicatt.it; Tel.: +39-0523-599-254
}

Received: 10 May 2018; Accepted: 24 May 2018; Published: 14 February 2019

The authors wish to make the following correction to their paper [1].

In Section 2.3, Mating-Type and Microsatellites, the first sentence should be replaced with "Amplification of the mating type genes revealed that strain A2321 has the idiomorph MAT1-2 and strain A2085 has the idiomorph MAT1-1."

We apologize for any inconvenience caused to readers of Toxins by this change.

\section{Reference}

1. Mauro, A.; Garcia-Cela, E.; Pietri, A.; Cotty, P.J.; Battilani, P. Biological Control Products for Aflatoxin Prevention in Italy: Commercial Field Evaluation of Atoxigenic Aspergillus flavus Active Ingredients. Toxins 2018, 10, 30. [CrossRef] [PubMed]

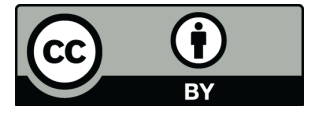

(C) 2019 by the authors. Licensee MDPI, Basel, Switzerland. This article is an open access article distributed under the terms and conditions of the Creative Commons Attribution (CC BY) license (http://creativecommons.org/licenses/by/4.0/). 